\title{
Prolactin and $\mathrm{LH}$ release in response to $\mathrm{LH}-\mathrm{RH}$ and TRH in ewes during dioestrus, pregnancy and post partum
}

\author{
P. J. Wright*, G. Jenkin $\dagger$ and R. B. Heap \\ A.R.C. Institute of Animal Physiology, Babraham, Cambridge CB2 4AT, U.K.
}

\begin{abstract}
Summary. With advancing pregnancy in the ewe there was a marked decline in plasma LH concentrations and pituitary LH-RH responsiveness (integrated LH release) and a marked increase in plasma prolactin values and pituitary TRH responsiveness (integrated prolactin release). In lactating ewes plasma $\mathrm{LH}$ levels and pituitary LH-RH responsiveness had returned to values found in the luteal phase of the normal cycle by 21 days post partum, whereas at 42 days post partum prolactin levels were still high. No interaction between TRH and LH-RH on prolactin and LH release in dioestrous ewes was detected. In non-pregnant ewes plasma prolactin levels were significantly higher in June than in January but TRH responsiveness was similar. It is concluded that, in sheep, pituitary LH secretion recovers more rapidly from the chronic negative feedback effect of oestrogens and progesterone in pregnancy than prolactin secretion recovers from the chronic positive feedback effects of oestrogens. This finding may be a contributory factor in the resistance to resumption of breeding activity.
\end{abstract}

\section{Introduction}

With advancing pregnancy in the ewe there is a progressive and marked decline in pituitary $\mathrm{LH}$ content, plasma LH levels and in the amount of $\mathrm{LH}$ released in response to exogenous luteinizing hormone-releasing hormone, LH-RH (Chamley, Findlay, Cumming, Buckmaster \& Goding, 1974a; Jenkin, Heap \& Symons, 1977; Chamley, Jonas \& Parr, 1976). Conversely, plasma prolactin levels increase markedly in the last third of pregnancy (Kann \& Denamur, 1974). Studies of anoestrous ewes, treated with progesterone or progesterone and oestradiol-17 $\beta$ in quantities similar to late pregnancy production rates, suggested that the pregnancy-associated decrease in LH synthesis and release was due to negative feedback effects of these steroids on the hypothalamo-pituitary system, and that the elevated plasma prolactin levels were due to a positive feedback effect of oestrogens (Wright, Jenkin, Heap \& Walters, 1978). Furthermore, ewes treated with oestradiol and progesterone showed an increased prolactin release in response to exogenous thyrotrophin releasing hormone, TRH, suggesting that TRH responsiveness would be increased in pregnancy. However, in a small study this was not demonstrated (Chamley, 1978). In this paper we have investigated this apparent discrepancy in greater detail. Prolactin concentrations in peripheral plasma were measured before and after the injection of TRH in the same ewes during dioestrus, pregnancy and in the post-partum period. In addition, plasma LH

\footnotetext{
* Present address: Department of Veterinary Clinical Sciences, University of Melbourne, Werribee, Victoria 3030 , Australia.

† Present address: Department of Physiology, University of Queensland, St Lucia, Queensland 4067, Australia.
} 
levels were measured in the same samples before and after LH-RH administered simultaneously with TRH. Since Wright et al. (1978) found that pituitary responsiveness to the two releasing hormones appeared to be inversely related, the present experiments were designed to examine whether pituitary secretion of prolactin and $\mathrm{LH}$ recovered at similar rates during the post-partum period from the feedback effects of ovarian and placental steroids in pregnancy. Non-pregnant ewes were used as controls to account for any effect of season. Initially, the possible interaction between LH-RH and TRH was investigated by administration of both hormones with measurement of the release of $\mathrm{LH}$ and prolactin. In all experiments a large dose of LH-RH and TRH was used as in previous studies to achieve a maximum pituitary response to a single injection of the releasing hormones.

\section{Materials and Methods}

\section{Animals}

Mature ewes predominantly of the Clun Forest breed were used and kept in paddocks adjacent to the laboratory. Sheep were placed in individual pens at least $24 \mathrm{~h}$ before injection of releasing hormones and were allowed free access to food and water.

\section{Pituitary responsiveness to $L H-R H$ and $T R H$}

A polyvinyl catheter (Portex NT3, SH90; $1.4 \mathrm{~mm}$ i.d., $2.0 \mathrm{~mm}$ o.d.) was inserted into a jugular vein on the day before the releasing hormones were given.

Sheep were given $200 \mu \mathrm{g}$ of the synthetic decapeptide, LH-RH, and/or $10 \mu \mathrm{g}$ of the synthetic tripeptide, TRH (Hoechst Pharmaceuticals) in $2 \mathrm{ml} 0.154 \mathrm{M}-\mathrm{NaCl}$ through the jugular vein catheter. Blood samples $(6 \mathrm{ml})$ were taken from the same catheter into heparinized syringes every $15 \mathrm{~min}$ for $2 \mathrm{~h}$ before and each $5 \mathrm{~min}$ for $0.5 \mathrm{~h}$ after injection, every $15 \mathrm{~min}$ for the next $1.5 \mathrm{~h}$, and then every 20-30 min for a further $4 \mathrm{~h}$. Blood was chilled at collection, centrifuged promptly and stored at $-20^{\circ} \mathrm{C}$ until assay.

The basal plasma concentrations of $\mathrm{LH}$ and prolactin were calculated as the mean of the values for blood samples taken over the $2 \mathrm{~h}$ before administration of LH-RH and TRH. The responsiveness of the pituitary to $\mathrm{LH}-\mathrm{RH}$ and TRH was assessed by measuring the area under the curve of $\mathrm{LH}$ and prolactin release for $360 \mathrm{~min}$ from the time of injection and correcting for basal release as described previously (Wright et al., 1978). The integrated values are given as $\log _{\mathrm{e}}$ $\mathrm{ng} / \mathrm{ml} . \tau_{1}$ corresponding to the integrated area B depicted in Text-fig. 1 of Wright et al. (1978).

\section{Effect of simultaneous treatment with $L H-R H$ and TRH on pituitary responsiveness}

During January and February, 8 ewes were treated with LH-RH or TRH, or LH-RH + TRH between Days 8 and 12 of three successive oestrous cycles (day of oestrus = Day 0 ) and pituitary responsiveness was assessed. Treatments were applied in a Latin Square design to negate the effect of time.

\section{Effect of season on pituitary responsiveness to $T R H$}

Pituitary responsiveness to TRH was assessed in 6 non-pregnant ewes between Days 8 and 12 of dioestrus (January) and repeated later in the year when the animals were anoestrous (June).

\section{Pituitary responsiveness to $L H-R H$ and $T R H$ during dioestrus, pregnancy and post-partum} anoestrus

This study involved 10 ewes that had mated in January and produced live lambs in June after a normal gestation period. Plasma $\mathrm{LH}$ and prolactin levels and pituitary responsiveness to 
LH-RH and TRH were determined between Days 8 and 12 of dioestrus, on Days 9, 50, 100 and 130 of pregnancy, and on Days 3, 14 to 21 and 42 post partum. Amongst the animals studied post partum, 5 were suckling lambs and 5 lost their lambs at birth. Prolactin values were determined for all 10 ewes, and LH values were measured in 9 of 10 animals. Technical problems precluded the analysis of all samples for $\mathrm{LH}$.

\section{Radioimmunoassays}

Plasma LH and prolactin values were determined by solid-phase and double-antibody radioimmunoassays as described previously (Wright et al., 1978). All LH measurements were determined in 3 assays and prolactin measurements in 8 assays. The lowest concentration of hormone distinguishable from zero (counts bound at zero concentration of hormone minus standard deviation $\times 2$ ) was $0.3 \pm 0.2$ (mean \pm s.e.m.) $\mathrm{ng} \mathrm{LH} / \mathrm{ml}$ and $5.8 \pm 1.9 \mathrm{ng}$ prolactin $/ \mathrm{ml}$. In the LH assay the intra- and inter-assay coefficients of variation were $6.3 \%(7 \cdot 1 \mathrm{ng}$ $\mathrm{NIH}-\mathrm{LH}-\mathrm{S} 17 / \mathrm{ml}, n=5)$ and $12.7 \%(n=3)$ respectively. In the prolactin (NIH-S11) assay the intra-assay coefficients of variation were $5.1 \pm 1.8$ and $3.2 \pm 1.2 \%$, and the inter-assay coefficients of variation were 11.5 and $8.4 \%$ for sheep plasma pools of 17.1 and $188.0 \mathrm{ng} / \mathrm{ml}$ $(n=8)$ respectively.

\section{Statistical analysis}

Analysis of variance was carried out on logarithmically transformed variables to achieve homogeneity of variance. Treatment means were compared by Duncan's new multiple range test. Seasonal differences were compared by using a paired $t$ test (Steele \& Torrie, 1960).

\section{Results}

\section{Lack of interaction between LH-RH and TRH administered simultaneously}

The prolactin and $\mathrm{LH}$ responses to TRH and LH-RH respectively were not significantly different $(P>0.05)$ when the releasing hormones were given simultaneously or on separate occasions (Table 1).

Table 1. Integrated values of prolactin and LH release after intravenous injection of $200 \mu \mathrm{g} \mathrm{LH}-\mathrm{RH}$ and/ or $10 \mu \mathrm{g}$ TRH in dioestrous ewes during 3 different oestrous cycles ( 8 ewes in each cycle)

\begin{tabular}{|c|c|c|c|c|c|c|}
\hline \multirow[b]{2}{*}{ Treatment } & \multirow[b]{2}{*}{ Code } & \multirow{2}{*}{$\begin{array}{c}\text { Integrated } \mathrm{LH} \\
\text { release } \\
\left(\mathrm{ng} / \mathrm{ml} . \tau_{1}\right)^{*}\end{array}$} & \multirow{2}{*}{$\begin{array}{l}\text { Statistical } \\
\text { significance } \\
(P<0.01)\end{array}$} & \multirow{2}{*}{$\begin{array}{l}\text { Integrated pro- } \\
\text { lactin release } \\
\left(\mathrm{ng} / \mathrm{ml} . \tau_{1}\right)^{*}\end{array}$} & \multicolumn{2}{|c|}{$\begin{array}{l}\text { Statistical } \\
\text { significance }\end{array}$} \\
\hline & & & & & $P<0.05$ & $P<0.01$ \\
\hline TRH & A & $0.4 \quad(8.6 \pm 0.05)$ & $\mathrm{B}, \mathrm{C}$ & $26.7(9.7 \pm 0.58)$ & 一 & B \\
\hline LH-RH & B & $17.5(10.0 \pm 0.16)$ & A & $1.4(8.8 \pm 0.13)$ & $\mathrm{C}$ & $\mathbf{A}$ \\
\hline TRH + LH-RH & $\mathrm{C}$ & $15.5 \quad(9.9 \pm 0.16)$ & A & $16.1(9.9 \pm 0.14)$ & B & - \\
\hline
\end{tabular}

Values are arithmetic means $\left(\times 10^{-3}\right)$ with $\log _{\mathrm{e}}$ mean value \pm s.e.m. after transformation $\left(\log _{\mathrm{e}}(x+100)\right)$ in parentheses.

\section{Pituitary responsiveness to TRH unaffected by season}

The mean basal plasma prolactin levels were higher in June than in January $(50.5 \pm 6.4$ compared with $11.3 \pm 3.4 \mathrm{ng} / \mathrm{ml}, P<0.01$ ). However, no significant difference in TRH responsiveness was detected $\left(23.28 \pm 5.75\right.$ and $\left.18.8 \pm 3 \cdot 12 \mathrm{ng} / \mathrm{ml} . \tau_{1} \times 10^{-3}, P>0.05\right)$. 
Pituitary responsiveness to $\mathrm{LH}-\mathrm{RH}$ and $\mathrm{TRH}$ in ewes during dioestrus, pregnancy and post-partum anoestrus

Basal plasma LH values were lower at 130 days of pregnancy and 3 days post partum (Table 2). LH-RH responsiveness was reduced at 50 days of pregnancy and declined to lower levels at 100 and 130 days. By 14-21 days post partum LH-RH responsiveness had returned to values similar to those observed at dioestrus, and at Days 9 and 50 of gestation.

Table 2. Basal concentration of $\mathrm{LH}$ and integrated values of $\mathrm{LH}$ release after simultaneous intravenous injection of $200 \mu \mathrm{g} \mathrm{LH}-\mathrm{RH}$ and $10 \mu \mathrm{g} \mathrm{TRH}$ in the same ewes during dioestrus, pregnancy and postpartum anoestrus

\begin{tabular}{|c|c|c|c|c|c|c|c|c|c|}
\hline \multirow{2}{*}{\multicolumn{2}{|c|}{$\begin{array}{l}\text { Reproductive } \\
\text { state of ewes }\end{array}$}} & \multirow[b]{2}{*}{ Code } & \multirow{2}{*}{$\begin{array}{l}\text { No. of } \\
\text { animals }\end{array}$} & \multirow{2}{*}{$\begin{array}{c}\text { Basal } \\
\text { concentration } \\
(\mathrm{ng} / \mathrm{ml})^{*}\end{array}$} & \multicolumn{2}{|c|}{$\begin{array}{l}\text { Statistical } \\
\text { significance }\end{array}$} & \multirow{2}{*}{$\begin{array}{l}\text { Integrated release } \\
\qquad\left(\mathrm{ng} / \mathrm{ml} \tau_{1}\right) \dagger\end{array}$} & \multicolumn{2}{|c|}{$\begin{array}{l}\text { Statistical } \\
\text { significance }\end{array}$} \\
\hline & & & & & $P<0.05$ & $P<0.01$ & & $P<0.05$ & $P<0.01$ \\
\hline \multicolumn{2}{|c|}{ Dioestrous } & A & 9 & $1.9(0.5 \pm 0.22)$ & F & $\mathrm{E}$ & $13.8 \quad(9.4 \pm 0.19)$ & $\mathrm{C}$ & $\mathrm{D}, \mathrm{E}, \mathrm{F}$ \\
\hline \multirow[t]{4}{*}{ Pregnant } & 9 days & B & 9 & $2.0(0.5 \pm 0.23)$ & $\mathrm{F}$ & $\mathrm{E}$ & $12 \cdot 2 \quad(9.3 \pm 0 \cdot 16)$ & $\mathrm{C}$ & $\mathrm{D}, \mathrm{E}, \mathrm{F}$ \\
\hline & 50 days & $\mathrm{C}$ & 9 & $1.2(0.07 \pm 0.23)$ & & & $5.0 \quad(8.3 \pm 0.21)$ & A, B & $\mathrm{D}, \mathrm{E}, \mathrm{F}$ \\
\hline & 100 days & D & 9 & $1.3(0.19 \pm 0.15)$ & $\mathrm{E}$ & & $0.6 \quad(6.1 \pm 0.39)$ & $\mathbf{F}$ & A, B, C, G \\
\hline & 130 days & $\mathbf{E}$ & 9 & $1.0(-0.39 \pm 0.35)$ & D & $A, B, C$ & $0.96(6.4 \pm 0.34)$ & & $A, B, C, G$ \\
\hline \multicolumn{10}{|c|}{ Post-partum anoestrous } \\
\hline \multicolumn{2}{|c|}{3 days } & $\mathbf{F}$ & 9 & $1.2(-0.03 \pm 0.21)$ & $\mathrm{A}, \mathrm{B}, \mathrm{G}$ & & $1.7 \quad(6.9 \pm 0.31)$ & D & $A, B, C, G$ \\
\hline \multicolumn{2}{|c|}{ 14-21 days } & $G$ & 9 & $2.0(0.55 \pm 0.21)$ & $\mathrm{F}$ & $\mathrm{E}$ & $8.7 \quad(9.0 \pm 0.17)$ & & $\mathrm{D}, \mathrm{E}, \mathrm{F}$ \\
\hline \multicolumn{2}{|c|}{42 days } & & 3 & $2.6(0.45 \pm 0.79)$ & & & $13.8 \quad(9.5 \pm 0.16)$ & & \\
\hline
\end{tabular}

* Arithmetic mean value with $\log _{\mathrm{e}}$ mean value \pm s.e.m. in parentheses.

+ Arithmetic mean value $\left(\times 10^{-3}\right)$ with $\log _{\mathrm{e}}$ mean value \pm s.e.m. in parentheses.

Table 3. Basal concentration of prolactin and integrated values of prolactin release after simultaneous intravenous injection of $200 \mu \mathrm{g} \mathrm{LH}-\mathrm{RH}$ and $10 \mu \mathrm{g}$ TRH in the same ewes during dioestrus, pregnancy and post-partum anoestrus

\begin{tabular}{|c|c|c|c|c|c|c|c|c|}
\hline \multirow{2}{*}{$\begin{array}{l}\text { Reproductive } \\
\text { state of ewes }\end{array}$} & \multirow[b]{2}{*}{ Code } & \multirow{2}{*}{$\begin{array}{l}\text { No. of } \\
\text { animats }\end{array}$} & \multirow{2}{*}{$\begin{array}{c}\text { Basal } \\
\text { concentration } \\
(\mathrm{ng} / \mathrm{ml})^{*}\end{array}$} & \multicolumn{2}{|c|}{$\begin{array}{l}\text { Statistical } \\
\text { significance }\end{array}$} & \multirow{2}{*}{$\begin{array}{l}\text { After treatment } \\
\text { response } \\
\left(\mathrm{ng} / \mathrm{ml} . \tau_{1}\right) \dagger\end{array}$} & \multicolumn{2}{|c|}{$\begin{array}{l}\text { Statistical } \\
\text { significance }\end{array}$} \\
\hline & & & & $P<0.05$ & $P<0.01$ & & $P<0.05$ & $P<0.01$ \\
\hline Dioestrous & A & 10 & $15.1(2.4 \pm 0.26)$ & $\mathrm{C}$ & $\mathrm{D}, \mathrm{E}, \mathrm{F}, \mathrm{G}, \mathrm{H}$ & $14 \cdot 1 \quad(9.2 \pm 0.31)$ & - & D, E, F, G, H \\
\hline Pregnant 9 days & B & 10 & $22.3(2.86 \pm 0.26)$ & 一 & D. E. F, G. H & $20.8 \quad(9.7 \pm 0.32)$ & $\mathrm{D}$ & $E, F, G, H$ \\
\hline 50 days & C & 10 & $27.5(2.97 \pm 0.30)$ & A & $\mathrm{D}, \mathrm{E}, \mathrm{F}, \mathrm{G}, \mathrm{H}$ & $22.0 \quad(9.4 \pm 0.52)$ & - & D, E, F, G, H \\
\hline Pregnant & D & 10 & $157(5.0 \pm 0.11)$ & F, G, H & A, B, C, E & $31.9(10.1 \pm 0.25)$ & $\mathrm{B}, \mathrm{F}, \mathrm{G}$ & A, C, E \\
\hline 130 days & $\mathbf{E}$ & 10 & $341(5.8 \pm 0.09)$ & - & A, B, C, D & $88.7(11.2 \pm 0.21)$ & $\mathbf{F}$ & A, B, C, D, H \\
\hline \multicolumn{9}{|l|}{ Post-partum anoestrous } \\
\hline \multirow[t]{3}{*}{3 days } & $\mathbf{F}$ & 10 & $300(5.6 \pm 0.15)$ & $\mathrm{D}$ & A, B, C & $52.5(10.7 \pm 0.23)$ & $\mathrm{D}, \mathrm{E}$ & A, B, C \\
\hline & & $5(\mathrm{~S})$ & $373(5.9 \pm 0.12) \ddagger$ & - & - & $42.8(10.4 \pm 0.37)$ & - & - \\
\hline & & $5(W)$ & $226(5.3 \pm 0.22)$ & - & - & $62.3(10.9 \pm 0.26)$ & - & - \\
\hline \multirow[t]{3}{*}{ 14-21 days } & G & 10 & $291(5.6 \pm 0.12)$ & D & A, B, C & $65.3(10.8 \pm 0.34)$ & $\mathrm{D}$ & $A, B, C$ \\
\hline & & $5(S)$ & $313(5.7 \pm 0.20) \neq$ & 一 & - & $54.8(10.5 \pm 0.64)$ & - & - \\
\hline & & $5(W)$ & $268(5.6 \pm 0.11)$ & - & - & $75.7(11.2 \pm 0.21)$ & - & - \\
\hline \multirow[t]{3}{*}{42 days } & $\mathbf{H}$ & 8 & $280(5.5 \pm 0.16)$ & $\mathrm{D}$ & $\mathrm{A}, \mathrm{B}, \mathrm{C}$ & $34.3(10.3 \pm 0.22)$ & - & A, B, C, E \\
\hline & & $4(S)$ & $344(5.8 \pm 0.09) \ddagger$ & - & - & $23.9(9.9 \pm 0.44)$ & - & - \\
\hline & & $4(W)$ & $216(5.3 \pm 0.21)$ & - & - & $44.6(10.65 \pm 0.16)$ & - & - \\
\hline
\end{tabular}

* Arithmetic mean value with $\log _{e}$ mean value \pm s.e.m. in parentheses.

+ Arithmetic mean value $\left(\times 10^{-3}\right)$ with $\log _{e}$ mean value \pm s.e.m. in parentheses.

$\ddagger$ Analysis of variance showed that values in suckled (S) ewes were significantly greater than those of non-suckled (W) ewes; $P<0.05$; stage post partum and interactions were not significant. 
Basal plasma prolactin concentrations were significantly greater at 100 days of pregnancy and were further increased at 130 days of pregnancy and up to 42 days post partum. TRH responsiveness was similarly elevated at 100 and 130 days of pregnancy and in the post-partum period (Table 3). The basal concentration of prolactin was significantly higher in suckling than in non-suckling ewes $(P<0.05)$, but the integrated release after TRH treatment was unaffected by lactational state (Table 3 ).

\section{Discussion}

This longitudinal study in ewes clearly demonstrates an inverse relation in pregnancy between a fall in plasma LH concentrations and LH-RH responsiveness, and an increase in plasma prolactin values and TRH responsiveness. Pituitary responsiveness to LH-RH was reduced from 50 days of pregnancy onwards and had returned to normal by 21 days post partum, whereas TRH responsiveness increased after 100 days of pregnancy and was still enhanced 42 days post partum. The findings in pregnant animals are consistent with our previous studies of anoestrous ewes which indicated that reduced plasma $\mathrm{LH}$ values and $\mathrm{LH}-\mathrm{RH}$ responsiveness may be due to the negative feedback effects of progesterone and oestrogen on the hypothalamo-pituitary system and that increased prolactin concentrations and TRH responsiveness may be due to positive feedback effects of oestradiol (Wright et al., 1978). A rapid fall in the circulating concentration of oestrogens (conjugated and unconjugated) and progesterone after parturition (see Heap, Galil, Harrison, Jenkin \& Perry, 1977) therefore appears to be associated with the removal of negative feedback on LH release. However, basal levels of prolactin in peripheral plasma and TRH-induced prolactin release remained high during the post-partum period. Only after 42 days was there any evidence for a slight reduction in prolactin concentrations towards values normally found in dioestrous or control anoestrous ewes, indicating that other factors must be operative in the reversal of positive feedback mechanisms associated with gestation.

The persistence of a high basal concentration of prolactin and of a large TRH-induced prolactin release after parturition was not due to seasonal factors alone. Pituitary prolactin secretion increases in non-pregnant ewes during a period of increasing daylength, as shown previously (Walton, McNeilly, McNeilly \& Cunningham, 1977; Thimonier, Ravault \& Ortavant, 1978), although the increase was insufficient to account for the hyperprolactinaemia observed in the present study. Moreover, the effect was not solely due to the incidence of lactation because induced release of prolactin was high in suckled and non-suckled ewes, although the basal concentration was significantly higher in suckled ewes. Studies of women have also shown that suckling is associated with high basal prolactin values (Aono, Shioji, Shoda \& Kurachi, 1977; Howie, McNeilly, McArdle, Smart \& Houston, 1980). Neither can the results be explained in terms of an interaction between TRH and LH-RH, because no such interaction was detectable in non-pregnant animals. Furthermore, the pattern of change in pituitary responsiveness to LH-RH throughout pregnancy and in the post-partum period was similar to that reported by Jenkin et al. (1977) for LH-RH alone, while that of prolactin secretion was very similar to that found during gestation by Fitzgerald, Evins \& Cunningham (1981) who used TRH alone. The large release of prolactin induced by TRH injections post partum is consistent with the high basal secretion of prolactin which occurred independently of releasing hormone injections. We are forced to conclude, therefore, that the removal of the feedback effects of ovarian and placental steroids at parturition results in a differential recovery post partum in respect of the pituitary secretion of LH and prolactin. Thus, pituitary LH secretion recovered more rapidly from the chronic negative feedback effect of oestrogens and progesterone in pregnancy than prolactin secretion recovered from the effects of chronic positive feedback of oestrogens. This finding may have important implications in the resistance to resumption of breeding activity in the ewe. The timing and degree of elevation of plasma prolactin concentrations during pregnancy vary widely between ewes 
(Kann \& Denamur, 1974), and this variability probably explains the failure of Chamley (1978) in a similar, but smaller, study to demonstrate the pregnancy-associated changes reported here for plasma prolactin levels and TRH responsiveness.

The findings that LH-RH in tissue culture promotes LH synthesis (Redding, Schally, Arimura \& Matsuo, 1972) and that immunization of rats against LH-RH results in pituitary LH depletion (Fraser, Gunn, Jeffcoate \& Holland, 1974; Fraser, Jeffcoate, Gunn \& Holland, 1975) suggested that $\mathrm{LH}-\mathrm{RH}$ is necessary for $\mathrm{LH}$ synthesis in vivo. Both progesterone and oestradiol can inhibit the pulsatile release of LH (Diekman \& Malven, 1973; Coppings \& Malven, 1976; Hauger, Karsch \& Foster, 1977), so that if the pulsatile release of LH reflects the pulsatile secretion of LH-RH (Lincoln \& Short, 1981), pituitary LH depletion in pregnant and progesterone-oestrogen-treated ewes may be due to inadequate LH-RH action on the pituitary. In respect of prolactin, evidence from rats suggests that oestrogen acts at hypothalamic (Ratner \& Meites, 1964; Fuxe, Hokfelt \& Nilsson, 1969; Ramirez \& McCann, 1964) and pituitary sites (Wolfe \& Chadwick, 1936; Nicoll \& Meites, 1964; Haug \& Gautvik, 1976), resulting in increased plasma prolactin levels. However, the significance of increased TRH responsiveness during pregnancy in sheep is unclear since it is not known whether TRH has a physiological role in prolactin release in sheep, or whether TRH release is affected during gestation. Furthermore, it is not known whether increased TRH responsiveness reflects increased pituitary prolactin content or simply an oestrogen-induced increase in TRH binding sites (De Lean, Ferland, Drouin, Kelley \& Labrie, 1977; De Lean, Garon, Kelley \& Labrie, 1977). While there is a pregnancy-associated decline in the amount of both $\mathrm{LH}$ and FSH released in response to exogenous LH-RH (Chamley et al., 1974a; Chamley, Findlay, Jonas, Cumming \& Goding, 1974b; Jenkin et al., 1977), there is only a parallel change in pituitary LH content (Chamley et al., 1976).

We thank the Lalor Foundation for a Research Fellowship (G.J.); Mr J. M. J. Best, Hoechst Pharmaceuticals, Hounslow, Middlesex, for gifts of releasing hormones; Dr L. E. Reichert and the National Institutes of Health, Bethesda, Maryland, U.S.A., for pituitary hormones; Dr J. R. McNeilly for a gift of prolactin antiserum; Miss Lesley Merrett for statistical assistance; and Mrs Lynn Magill and Mrs Dorothy George for typing.

\section{References}

Aono, T., Shioji, T., Shoda, T. \& Kurachi, K. (1977) The initiation of human lactation and prolactin response to suckling. J. clin. Endocr. Metab. 44, 1101-1106.

Chamley, W. A. (1978) Prolactin response to synthetic TRF in pregnant ewes. J. Reprod. Fert. 52, 297-299.

Chamley, W.A., Findlay, J.K., Cumming, I.A., Buckmaster, J.M. \& Goding, J.R. (1974a) Effect of pregnancy on the LH response to synthetic gonadotrophin-releasing hormone in the ewe. Endocrinology 94, 291-293.

Chamley, W.A., Findlay, J.K., Jonas, H., Cumming, I.A. \& Goding, J.R. (1974b) Effect of pregnancy on the FSH response to synthetic gonadotrophin-releasing hormone in ewes. J. Reprod. Fert. 37, 109-112.

Chamley, W.A., Jonas, H.A. \& Parr, R.A. (1976) Content of LH, FSH and growth hormone in the pituitaries of pregnant and anestrous sheep. Endocrinology 98, 1535-1538.

Coppings, R.J. \& Malven, P.V. (1976) Biphasic effect of estradiol on mechanisms regulating $\mathrm{LH}$ release in ovariectomized sheep. Neuroendocrinology 21, 146156.
De Lean, A., Garon, M., Kelley, P.A. \& Labrie, F. (1977) Changes of pituitary hormone (TRH) receptor level and prolactin response to TRH during the rat estrous cycle. Endocrinology 100, 1505-1510.

De Lean, A., Ferland, L., Drouin, J., Kelley, P.A. \& Labrie, F. (1977) Modulation of pituitary thyrotropin-releasing hormone receptor levels by estrogens and thyroid hormones. Endocrinology 100, 1496-1504.

Diekman, M.A. \& Malven, P.V. (1973) Effect of ovariectomy and estradiol on LH patterns in ewes. $J$. Anim. Sci. 37, 562-567.

Fitzgerald, B.P., Evins, J.D. \& Cunningham, F.J. (1981) Effect of TRH on the secretion of prolactin in ewes at various stages of pregnancy and in non-pregnant ewes during the breeding season and seasonal anoestrus. J. Reprod. Fert. 61, 149-155.

Fraser, H.M., Gunn, A., Jefícoate, S.L. \& Holland, D.T. (1974) Effect of active immunisation to luteinizing hormone releasing hormone on serum and pituitary gonadotrophins, testes and accessory sex organs in the male rat. $J$. Endocr. 63, 399-406. 
Fraser, H.M., Jeffcoate, S.L., Gunn, A. \& Holland, D.T. (1975) Effect of active immunization to luteinizing hormone releasing hormone on gonadotrophin levels in ovariectomized rats. J. Endocr. 64, 191-192.

Fuxe, G.A., Hokfelt, T. Nilsson, O. (1969) Castration, sex hormones and tubero-infundibular dopamine neurones. Neuroendocrinology 5, 107-120.

Haug, E. \& Gautvik, K.M. (1976) Effects of sex steroids on prolactin secreting rat pituitary cells in culture. Endocrinology 99, 1482-1489.

Hauger, R.L., Karsch, F.J. \& Foster, D.L. (1977) A new concept for control of the estrous cycle of the ewe based on the temporal relationships between luteinising hormone, estradiol and progesterone in peripheral serum and evidence that progesterone inhibits tonic LH secretion. Endocrinology 101, 807-817.

Heap, R.B., Galil, A.K.A., Harrison, F.A., Jenkin, G. \& Perry, J.S. (1977) Progesterone and oestrogen in pregnancy and parturition: comparative aspects and hierarchical control. In The Fetus and Birth (Ciba Fdn Symp. No. 47), pp. 127-157. Elsevier, Amsterdam.

Howie, P.W., McNeilly, A.S., McArdle, T., Smart, L. \& Houston, M. (1980) The relationship between suckling-induced prolactin response and lactogenesis. J. clin. Endocr. Metab. 50, 670-673.

Jenkin, G., Heap, R.B. \& Symons, D.B.A. (1977) Pituitary responsiveness to synthetic $\mathrm{LH}-\mathrm{RH}$ and pituitary $\mathrm{LH}$ content at various reproductive stages in sheep. J. Reprod. Fert. 49, 207-214.

Kann, G. \& Denamur, R. (1974) Possible role of prolactin during the oestrous cycle and gestation in the ewe. J. Reprod. Fert. 39, 473-483.

Lincoln, G.A. \& Short, R.V. (1981) Seasonal breeding: nature's contraceptive. Recent Prog. Horm. Res. 36, $1-52$.

Nicoll, C.S. \& Meites, J. (1964) Prolactin secretion in vitro: effects of gonadal and adrenal cortical steroids. Proc. Soc. exp. Biol. Med. 117, 579-583.

Ramirez, V.D. \& McCann, S.M. (1964) Induction of prolactin secretion by implants of estrogen into the hypothalamo-hypophyseal region of female rats. Endocrinology 75, 206-214.

Ratner, A. \& Meites, J. (1964) Depletion of prolactin inhibiting activity of the rat hypothalamus by estradiol or suckling stimulus. Endocrinology 75, 377-382.

Redding, T.W., Schally, A.V., Arimura, A. \& Matsuo, H. (1972) Stimulation of release and synthesis of luteinizing hormone ( $\mathrm{LH})$ and follicle stimulating hormone (FSH) in tissue cultures of rat pituitaries in response to natural and synthetic $\mathrm{LH}$ and FSH releasing hormone. Endocrinology 90, 764-770.

Steel, R.D.G. \& Torrie, J.H. (1960) Principles and Procedures of Statistics, McGraw Hill, New York.

Thimonier, J., Ravault, J.P. \& Ortavant, R. (1978) Plasma prolactin variations and cyclic ovarian activity in ewes submitted to different light regimes. Annls Biol. anim. Biochim. Biophys. 18, 1229-1235.

Walton, J.S., MeNeilly, J.R., McNeilly, A.S. \& Cunningham, F.J. (1977) Changes in concentrations of follicle-stimulating hormone, luteinizing hormone, from anoestrus to breeding activity. J. Endocr. 75, $127-136$.

Wolfe, J.M. \& Chadwick, C.S. (1936) Quantitative studies on the structural changes induced in the anterior hypophysis by injections of oestrin. Endocrinology 20, 503-510.

Wright, P.J., Jenkin, G., Heap, R.B. \& Walters, D.E. (1978) Pituitary responsiveness to LH-RH and TRH and the effects of progesterone or progesterone and oestradiol treatment in anoestrous sheep. $J$. Reprod. Fert. 52, 343-348. 